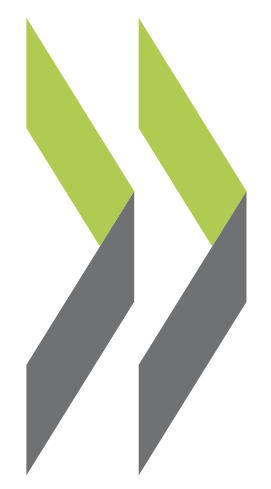

OECD Science, Technology and Industry Working Papers $2021 / 13$

Methodology for estimation of Energy Physical Supply and Use Tables based on IEA's World Energy Balances

\section{Joaquim Martins Guilhoto,}

Nick Johnstone,

Francesco Mattion, Faidon Papadimoulis, Roberta Quadrelli, Colin Webb 


\section{OECD Science, Technology and Industry Working Papers}

OECD Working Papers should not be reported as representing the official views of the OECD or of its member countries. The opinions expressed and arguments employed are those of the authors. Working Papers describe preliminary results or research in progress by the author(s) and are published to stimulate discussion on a broad range of issues on which the OECD works. Comments on Working Papers are welcomed, and may be sent to OECD Directorate for Science, Technology and Innovation, OECD, 2 rue André-Pascal, 75775 Paris Cedex 16, France; e-mail: sti.contact@oecd.org.

This document, as well as any data and any map included herein, are without prejudice to the status of or sovereignty over any territory, to the delimitation of international frontiers and boundaries and to the name of any territory, city or area.

(C) OECD (2021)

The use of this work, whether digital or print, is governed by the Terms and Conditions to be found at http://www.oecd.org/termsandconditions. 


\title{
Methodology for Estimation of Energy Physical Supply and Use Tables based on IEA's World Energy Balances
}

\author{
Joaquim J.M. GUILHOTO*1, Nick JOHNSTONE ${ }^{\S}$, Francesco MATTION ${ }^{\S}$, \\ Faidon PAPADIMOULIS ${ }^{\S}$, Roberta QUADRELLI ${ }^{\S}$, and Colin $\mathrm{WEBB}^{*}$
}

\author{
* Organisation for Economic Co-operation and Development (OECD) \\ $\S$ International Energy Agency (IEA)
}

This working paper develops a methodology for the estimation of Energy Physical Supply and Use Tables (E-PSUTS) based on the IEA's World Energy Balances (WEB). The tables are similar in nature to those proposed by the United Nations (UN) System of Environmental Economic Accounting (SEEA). However, unlike the SEEA system, the proposed methodology is able to fully exploit, and be consistent, with the information on fuel transformation processes available in the WEB, a significant improvement.

The E-PSUTs, by themselves, can be used to derive robust energy indicators in physical units. However, the final goal of the modelling strategy is to use the estimated E-PSUTs as a key input into a hybrid methodological approach, an Energy Multi-Factor Input-Output (MF-IO) model, which links global energy production and consumption in physical units with global production and consumption in monetary units, allowing the development of novel indicators to provide a richer understanding of the multiple links between global energy systems and the global economy and, contribute to ongoing discussions related to climate change.

Furthermore, complementary analyses can be undertaken by linking the MF-IO model with other relevant variables such as industry value added and employment data. Additionally it can be used to estimate energy-related $\mathrm{CO}_{2}$ emissions indicators, allowing for improved estimates of "embodied" carbon emissions.

The document is a result of joint work between the IEA and the OECD.

Keywords: World Energy Balances, Physical Supply and Use Tables, Energy 


\section{Table of contents}

1. Introduction 5

2. Estimating Energy Physical Supply and Use Tables (E-PSUTs)..................................................... 7

2.1. Comparing the structure of the E-PSUTs in the UN SEEA Energy accounts and on the MF-

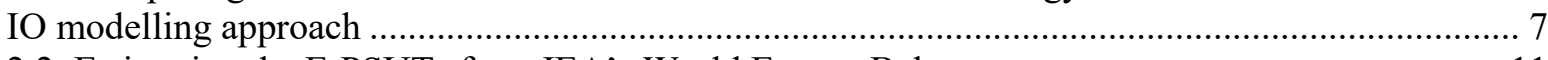

2.2. Estimating the E-PSUTs from IEA's World Energy Balances ............................................ 11

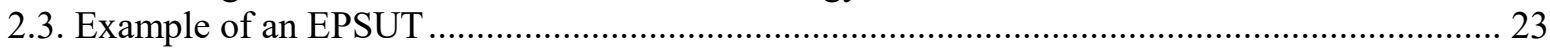

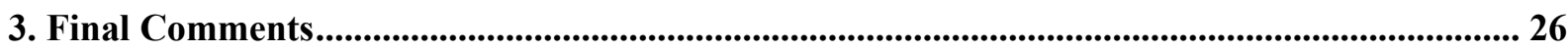

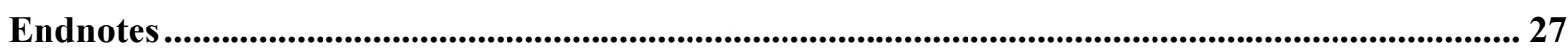

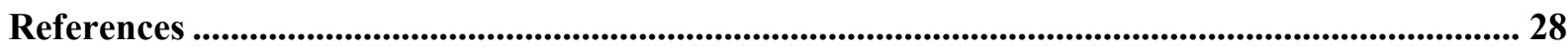

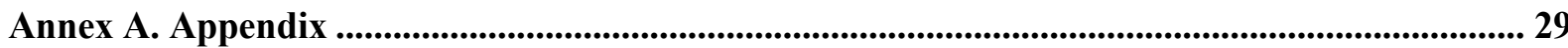

\section{FIGURES}

Figure 2.1. Going from IEA world energy balances to E-PSUTs $\quad 12$

Figure 2.2. Structure of IEA Energy Balances $\quad 13$

Figure 2.3. Structure of Energy Physical Supply Tables - EPSTs $\quad 15$

Figure 2.4. Structure of Energy Physical Use Tables - EPUTs 16

Figure 2.5. Structure of Energy Physical Import Tables - EPIMPs $\quad 17$

Figure 2.6. Structure of Energy Physical Distribution Losses Tables - EPDLs 18

Figure 2.7. Energy physical supply and use tables, an example 25

$\begin{array}{ll}\text { Figure A A.1. Map of fuel production processes to fuels production } & 29\end{array}$

\section{TABLES}

Table 2.1. Fuels from the WEB used in the E-PSUTs 9

$\begin{array}{lr}\text { Table 2.2. Fuel transformation processes } & 10\end{array}$

$\begin{array}{lr}\text { Table 2.3. Final demand elements } & 10\end{array}$

Table 2.4. Matrices and Dimensions $\quad 19$ 


\section{Introduction}

This paper proposes a methodology to estimate Energy Physical Supply and Use Tables (E-PSUTs) based on the International Energy Agency's World Energy Balances (IEA, $2020)^{2}$. The estimated E-PSUTs are designed to be a key input into the generation of new hybrid energy indicators that associate physical energy production and consumption with monetary production and consumption of energy, goods, and services, taking into account the different fuel types and fuel production processes.

The tables are similar in nature to those proposed by the United Nations (UN) System of Environmental Economic Accounting (SEEA), (UN, 2016; UN, 2019). However, unlike the SEEA system, through use of the energy balances we are able to exploit available information on fuel transformation processes, a significant improvement, as it will be possible to measure the direct and indirect fuels types required to produce primary and secondary energy. Consequently, the E-PSUTs, estimated according to the proposed methodology, can be used to derive robust energy indicators in physical units.

Such indicators have an important value in their own right. However, the construction of E-PSUTs in this joint OECD/IEA exercise is only the first step in a broader project. In the second stage, the aim is to link the E-PSUTs with national input-output tables (IOTs), in a hybrid model, with both energy and monetary units, allowing for a richer understanding of the use of energy by non-energy industries and, reveal the links between energy used in production processes with the energy incorporated in final demand of goods and services (termed "lifecycle energy indicators").

In the third stage, the system is "internationalised" through links with OECD's InterCountry Input-Output (ICIO) $)^{3}$ tables, which provide a globally balanced view of intercountry inter-industry flows of intermediate and final goods and services. The development of E-PSUTs can thus be considered as a first step in the construction of a Multi-Factor Input-Output (MF-IO) data infrastructure (Guevara and Domingos, 2017). Such a framework allows for a fuller understanding of the multiple links between the energy system and the economy, and thus analysis of a number of important policy questions (see section 2.1).

In the fourth stage, this structure could be complemented by linking the MF-IO structure with other relevant variables such as value added and employment data. Another important example is energy-related $\mathrm{CO}_{2}$, with the modelling structure allowing for improved estimates of "embodied" carbon emissions, e.g. per unit of value added and fuel type, in addition to emissions by industrial activity. This has important policy implications, allowing for the analysis of so-called carbon leakage i.e. the extent to which mitigation efforts in one region could be undermined by imports of embodied emissions for domestic final demand through internationally fragmented production processes.

However, even at this first stage, the work undertaken allows for the generation of a range of pertinent indicators, reflecting how these links vary across time and countries. For example, the evolution over time of a country's energy inputs (disaggregated by fuel type) per unit of value added at the industry level.

This allows for a much richer understanding of developments in factors such as sectoral energy intensity - i.e. to what extent are positive trends in a given sector undermined or reinforced by trends in upstream sectors, which are important sources of intermediate inputs (energy and non-energy). For example, does the use of more energy-efficient practices in a given sector involve the use of intermediate inputs from other sectors 
6 | ESTIMATION OF ENERGY PHYSICAL SUPPLY AND USE TABLES BASED ON IEA'S WORLD ENERGY BALANCES

(materials and equipment) which are themselves more (or less) energy-intensive in production? A further report will summarise the results of this work in terms of indicators that highlight trends by country and industrial activity. 


\section{Estimating Energy Physical Supply and Use Tables (E-PSUTs)}

This section details the methodology to estimate E-PSUTs from IEA's World Energy Balances (WEB). First, we highlight the main similarities and differences between the EPSUTs proposed here and the approach presented by the UN SEEA Energy accounts; next, it presents the methodology used to estimate the EPSUTs based on IEA Energy Balances.

\subsection{Comparing the structure of the E-PSUTs in the UN SEEA Energy accounts and on the MF-IO modelling approach}

Section 3.4 of UN (2019) describes the transition from energy balances to the estimation of E-PSUTs according to SEEA principles. However, the UN approach does not fully align with our aim to preserve all the information in the WEB - rather, the UN makes adjustments to conform to the standards in the SEEA Energy accounts (SEEA-E). ${ }^{4}$

As with the SEEA-E, this work understands the importance of distinguishing between the main industries that produce energy, namely:

1. Mining and quarrying:

a. ISIC Division 05-Mining of coal and lignite;

b. ISIC Division 06-Extraction of crude petroleum and natural gas.

2. Energy production:

a. ISIC Group 191-Manufacture of coke oven products;

b. ISIC Group 192-Manufacture of refined petroleum products;

c. ISIC Group 351-Electric power generation, transmission and distribution;

d. ISIC Group 352-Manufacture of gas; distribution of gaseous fuels through mains;

e. ISIC Group 353-Steam and air conditioning supply

As noted earlier, we exploit available information on fuel transformation processes, information that is not reflected in the SEEA accounts. Such information is important for the estimation of indicators (in physical terms) which take into account primary and secondary energy and information on the energy required to produce energy. In that sense, the focus of this work is more on fuels and fuel transformation processes than on the industry classification. The links between the (ISIC Rev.4) industry classification and fuel use categories are established when developing a full MF-IO hybrid model, i.e. considering both energy and monetary units, to be discussed in a future document.

In the present methodology, the structure of fuels and fuel transformation processes from the WEB (IEA 2020) are fully considered. However, the way they are presented and treated differs from the WEB to adjust to the structure of the E-PSUTs. Fuels that are primary energy appear first in the list, followed by fuels that can be either primary or secondary energy, and then those identified as secondary energy - see Table 2.1. Concerning the primary energy transformation processes, some primary industries present in the E-PSUT (with codes "Xxx_PRIMARY") do not appear directly in the WEB and were created to reconcile and link the structure of these two databases.

Table 2.2 presents first the transformation processes that essentially produce primary energy, followed by those that can produce either type of energy, Annex A presents which 
fuels are produced by each transformation process, identifying if the fuel produced is primary or secondary. The above ISIC Rev.4 energy producing sectors $(05,06,191,192$, 351,352 and 353) do not appear on the demand side (Table 2.3), which only includes the sectors that use energy. Consistent with the treatment in IEA's WEB, sectors that eventually produce energy, but for which the primary focus of their production is on nonenergy goods are, however, considered on the demand side.

With a view to eventual integration into a MF-IO hybrid model, the E-PSUTs proposed here, will:

1. Avoid the problem of relative prices, i.e., different consumers paying different prices for the same fuel. This is one of the advantages of working with hybrid energy models. For a detailed explanation see Miller and Blair (2019, chapter 9) and Wyckoff et al. (1990);

2. Respect the energy conservation principle, i.e., the conservation of embodied energy establishes that the energy embodied in the output of an industry is equal to the energy embodied in its intermediate inputs plus its direct energy inputs;

3. Ensure a consistent interconnection between the energy and non-energy industries, including industries that generate energy although it is not their primary focus of production; and,

4. Allow for the breakdown of the use of energy in the final demand of energy and non-energy industries by different types of fuels and by direct and indirect energy use. 
Table 2.1. Fuels from the WEB used in the E-PSUTs

\begin{tabular}{|c|c|c|c|}
\hline Code & Description & Code & Description \\
\hline HARDCOAL & Hard coal (if no detail) & NATGAS_S & Natural gas secondary \\
\hline BROWN & Brown coal (if no detail) & NONCRUDE_S & Other hydrocarbons secondary \\
\hline ANTCOAL & Anthracite & HEAT_S & Heat secondary \\
\hline COKCOAL & Coking coal & PATFUEL & Patent fuel \\
\hline BITCOAL & Other bituminous coal & OVENCOKE & Coke oven coke \\
\hline SUBCOAL & Sub-bituminous coal & GASCOKE & Gas coke \\
\hline LIGNITE & Lignite & COALTAR & Coal tar \\
\hline PEAT & Peat & BKB & Brown coal briquettes \\
\hline OILSHALE & Oil shale and oil sands & GASWKSGS & Gas works gas \\
\hline CRNGFEED & Crude/NGL/feedstocks (if no detail) & COKEOVGS & Coke oven gas \\
\hline CRUDEOIL & Crude oil & BLFURGS & Blast furnace gas \\
\hline NGL & Natural gas liquids & OGASES & Other recovered gases \\
\hline ADDITIVE & Additives/blending components & PEATPROD & Peat products \\
\hline NUCLEAR & Nuclear & REFFEEDS & Refinery feedstocks \\
\hline HYDRO & Hydro & REFINGAS & Refinery gas \\
\hline INDWASTE & Industrial waste & ETHANE & Ethane \\
\hline MUNWASTER & Municipal waste (renewable) & LPG & Liquefied petroleum gases (LPG) \\
\hline MUNWASTEN & Municipal waste (non-renewable) & NONBIOGASO & Motor gasoline excl. biofuels \\
\hline PRIMSBIO & Primary solid biofuels & AVGAS & Aviation gasoline \\
\hline BIOGASES & Biogases & JETGAS & Gasoline type jet fuel \\
\hline BIOGASOL & Biogasoline & NONBIOJETK & Kerosene type jet fuel excl. biofuels \\
\hline BIODIESEL & Biodiesels & OTHKERO & Other kerosene \\
\hline BIOJETKERO & Bio jet kerosene & NONBIODIES & Gas/diesel oil excl. biofuels \\
\hline OBIOLIQ & Other liquid biofuels & RESFUEL & Fuel oil \\
\hline RENEWNS & $\begin{array}{l}\text { Non-specified primary biofuels and } \\
\text { waste }\end{array}$ & NAPHTHA & Naphtha \\
\hline GEOTHERM & Geothermal & WHITESP & White spirit and industrial spirit \\
\hline SOLARPV & Solar photovoltaics & LUBRIC & Lubricants \\
\hline SOLARTH & Solar thermal & BITUMEN & Bitumen \\
\hline TIDE & Tide, wave and ocean & PARWAX & Paraffin waxes \\
\hline WIND & Wind & PETCOKE & Petroleum coke \\
\hline OTHER & Other sources & ONONSPEC & Other oil products \\
\hline NATGAS_P & Natural gas primary & CHARCOAL & Charcoal \\
\hline NONCRUDE_P & Other hydrocarbons primary & ELECTR & Electricity \\
\hline HEAT_P & Heat primary & & \\
\hline
\end{tabular}

Source: Authors' elaboration based on IEA (2020). 
Table 2.2. Fuel transformation processes

\begin{tabular}{llll}
\hline Code & Description & Code & Description \\
\hline MINES_PRIMARY & Coal mines primary & MAINHEAT & Main activity producer heat plants \\
\hline OILGASEX_PRIMARY & Oil and gas extraction primary & AUTOHEAT & Autoproducer heat plants \\
NUCLEAR_PRIMARY & Nuclear primary & THEAT & Heat pumps \\
\hline HYDRO_PRIMARY & Hydro primary & TBOILER & Electric boilers \\
WASTE_PRIMARY & Waste primary & TELE & Chemical heat for electricity \\
BIOGAS_PRIMARY & Biogases primary & TBLASTFUR & Blast furnaces \\
\hline BIOLIQ_PRIMARY & Bioliquides primary & TGASWKS & Gas works \\
\hline BIOMASS_PRIMARY & Biomass primary & TCOKEOVS & Coke ovens \\
BIONS_PRIMARY & Biosolid primary & TPATFUEL & Patent fuel plants \\
\hline GEOTHERMAL_PRIMARY & Geothermal primary & TBKB & BKB/peat briquette plants \\
REN_ELE_PRIMARY & Renewable electricity primary & TREFINER & Oil refineries \\
\hline REN_HEAT_PRIMARY & Renewable heat primary & TPETCHEM & Petrochemical plants \\
NONCRUDE_PRIMARY & Other hydrocarbons primary & TCOALLIQ & Coal liquefaction plants \\
\hline OTHER_PRIMARY & Other primary & TGTL & Gas-to-liquids (GTL) plants \\
\hline MAINELEC & Main activity producer electricity plants & TBLENDGAS & For blended natural gas \\
\hline AUTOELEC & Autoproducer electricity plants & TCHARCOAL & Charcoal production plants \\
\hline MAINCHP & Main activity producer CHP* plants & TNONSPEC & Non-specified (transformation) \\
AUTOCHP & Autoproducer CHP* plants & & \\
\hline
\end{tabular}

Notes:

* CHP - combined heat and power

$\S$ Includes the transformation of natural gas for hydrogen manufacture and other non-specified transformation.

Source: Authors' elaboration based on IEA (2020).

\section{Table 2.3. Final demand elements}

\begin{tabular}{llll}
\hline Code & Description & Code & Description \\
MINING & Mining and quarrying & PIPELINE & Pipeline transport \\
CONSTRUC & Construction & WORLDMAR & World marine bunkers \\
IRONSTL & Iron and steel & DOMESNAV & Domestic navigation \\
CHEMICAL & Chemical and petrochemical & TRNONSPE & Non-specified (transport) \\
NONFERR & Non-ferrous metals & RESIDENT & Residential \\
NONMET & Non-metallic minerals & COMMPUB & Commercial and public services \\
TRANSEQ & Transport equipment & AGRICULT & Agriculture/forestry \\
MACHINE & Machinery & FISHING & Fishing \\
FOODPRO & Food and tobacco & ONONSPECFD & Final consumption not elsewhere specified \\
PAPERPRO & Paper, pulp and printing & NONENUSE & Non-energy use \\
\hline WOODPRO & Wood and wood products & MARBUNK & International marine bunkers \\
TEXTILES & Textile and leather & AVBUNK & International aviation bunkers \\
INONSPEC & Industry not elsewhere specified & EXPORTS & Exports \\
WORLDAV & World aviation bunkers & STOCKCHA & Stock changes \\
\hline DOMESAIR & Domestic aviation & TRANSFER & Transfers \\
ROAD & Road transport & STATDIFF & Statistical differences \\
\hline RAIL & Rail transport & DLFD & Distribution losses in final demand \\
\hline
\end{tabular}

Source: Authors' elaboration based on IEA (2020). 


\subsection{Estimating the E-PSUTs from IEA's World Energy Balances}

This section details the methodology to estimate the E-PSUTs from IEA's World Energy Balances, focussing on how energy is used to produce energy and not which industries produce energy. Part of this section draws from the works of IEA (2020), UN (2019 and 2017), Heun, Owen, and Brockway (2018), and Miller and Blair (2009).

Figure 2.1 shows, in a schematic way, the processes to transform information in the IEA World Energy Balances to the E-PSUTs. The elements from the energy balance are marked as "Engy Bal" while the elements of the E-PSUTs can be recognized as they are represented by the matrices show in Figure 2.3 to Figure 2.6. Negative values from the energy balance which need to be transformed into positive values, for reasons that will be discussed below, are represented by first going through a box showing "* - 1", where they are transformed into positive numbers through a multiplication by -1 .

We first present the overall structure of the IEA's World Energy Balances and then explain in detail the estimation procedure as they appear in each flow presented in Figure 2.1.

The IEA energy balances, Figure 2.2, can be divided into four major accounts:

1. TES, total energy supply;

2. TIC, total intermediate consumption;

3. TFS, total final supply; and

4. TFC, total final consumption.

While the TIC and the TFS accounts do not appear explicitly in the WEB, they can be easily derived, as shown in Figure 2.2.

In the TES and TIC accounts, the signs indicate if the items in these accounts contribute positively or negatively to the availability of the energy products in the economy. For example, in TES, production and imports contribute positively to the availability of energy in the economy, while exports, international bunkers and stock changes contribute negatively; overall, it is expected that the TES in the economy is positive (the sign in the column of Total). In the TIC, for the item transformation process, the outputs of the energy industries appear as positive and the inputs as negative, the other items are negative; overall, it is expected that the TIC in the economy appears as a negative number, showing the net, output less input, energy consumed in the transformation and distribution process.

The TFS is obtained by deducting from the TES the energy used in the TIC, as the energy used in TIC appears as negative i.e. TFS = TES + TIC. The result in TFS shows, by energy product, how much energy is available for final consumption in the economy (TFC), the energy consumed in the TFC appears as positive numbers. 
Figure 2.1. Going from IEA world energy balances to E-PSUTs

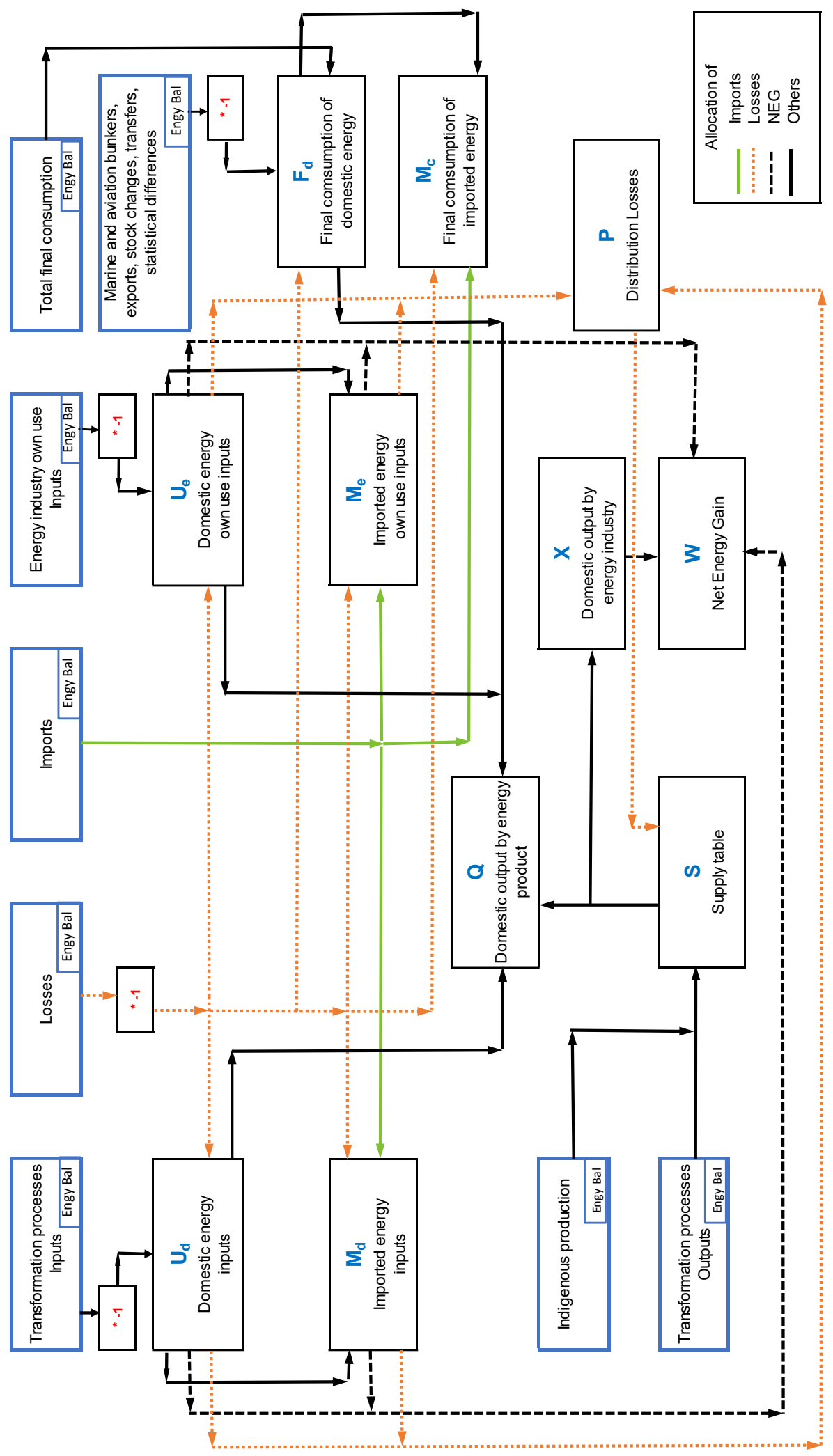

Source: Authors' elaboration. 
Figure 2.2. Structure of IEA Energy Balances

\begin{tabular}{|c|c|c|c|c|c|}
\hline \multicolumn{2}{|c|}{$\begin{array}{c}\text { IEA } \\
\text { ENERGY BALANCE }\end{array}$} & & Energy Products & \multicolumn{2}{|c|}{ Total } \\
\hline \multirow{6}{*}{$\begin{array}{c}\text { TES } \\
\text { Total } \\
\text { Energy Supply }\end{array}$} & Production & & + & \multirow{6}{*}{\multicolumn{2}{|c|}{$\begin{array}{c}+ \\
\text { (Positive) }\end{array}$}} \\
\hline & Imports & & + & & \\
\hline & Exports & & $=$ & & \\
\hline & International marine bunkers & & $=$ & & \\
\hline & International aviation bunkers & & $=$ & & \\
\hline & Stock changes & & $=$ & & \\
\hline \multirow{7}{*}{$\begin{array}{c}\text { TIC } \\
\text { Total Intermediate } \\
\text { Consumption }\end{array}$} & Transfers & & - & \multirow{7}{*}{\multicolumn{2}{|c|}{$\begin{array}{c}\text { - } \\
\text { (Negative) }\end{array}$}} \\
\hline & Statistical differences & & - & & \\
\hline & Transformation processes & & \multirow{3}{*}{ - } & & \\
\hline & Output & + & & & \\
\hline & Input & - & & & \\
\hline & Energy industry own use & & - & & \\
\hline & Losses & & $=$ & & \\
\hline TFS & TES & & + & $\begin{array}{c}\mathbf{+} \\
\text { (Positive) }\end{array}$ & \multirow{6}{*}{$\mathrm{TFS}=\mathrm{TFC}$} \\
\hline $\begin{array}{l}\text { Otal FInal } \\
\text { Supply }\end{array}$ & TIC & & - & $\mathrm{TFS}=\mathrm{TES}+\mathrm{TIC}$ & \\
\hline \multirow{4}{*}{$\begin{array}{c}\text { TFC } \\
\text { Total Final } \\
\text { Consumption }\end{array}$} & Industry & & + & \multirow{4}{*}{$\begin{array}{c}+ \\
\text { (Positive) }\end{array}$} & \\
\hline & Transport & & + & & \\
\hline & Other & & + & & \\
\hline & Non-energy use & & + & & \\
\hline
\end{tabular}

Source: Authors' elaboration based on IEA (2020).

The main idea behind the proposed E-PSUTs is to represent, in the best way possible, the fuel production process (energy industry) and the use of energy in the national economy, with a focus on the fuel type and the fuel transformation process presented in the WEB, as well as the information on the components of final consumption.

The integrated system proposed for the E-PSUTs is presented in Figure 2.3 to Figure 2.6, and the matrix notation is presented in Table 2.4. Each figure presents two sets of information, the first one shows a description of each account while the second one shows the matrix notation.

The Energy Physical Supply Tables (EPSTs) structure is presented in Figure 2.3, the columns show the producing industries and the rows show the fuels produced. Thus the supply table $(S)$ shows for each national fuel production process, which fuels are produced and in what quantity, i.e., a given fuel type can be produced by more than one fuel production process, and a fuel production process can produce more than one type of fuel. Note that the values are presented as energy less distribution losses, given that the distribution losses are subtracted from the total energy produced and are presented in the column Losses of the supply table. The columns show which industries produce a given fuel and the amount of distribution losses of the fuel in consideration, also note that these values of distribution losses refer only to national fuels as there are also distribution losses associated with imported inputs.

The Energy Physical Use Tables (EPUTs) structure is presented in Figure 2.4. The columns show the consumption of energy by the domestic energy producing industries, and by final users of energy; while the rows separate the energy consumed by its origin, domestic and imported, and by type of use: a) to produce energy; b) energy industry own use; c) distribution losses; and d) net energy gain. 
To produce the different fuels, the fuel production process can use domestic $\left(U_{d}\right)$ and imported $\left(M_{d t}\right)$ fuels. The fuel can either be used: a) as energy which is consumed by the producing industry for its own operations (industry own use, $U_{e}$ and $M_{e t}$ ), e.g., electricity which is used to power machinery in the industry; or b) as an input in the production process ( $U_{d}$ and $M_{d t}$ ), e.g., coal which is used in the generation of power.

By producing energy, the producing industries can have a surplus of energy, when the total energy produced (useable energy) is greater than the total input of energy, or a deficit of energy, when the useable energy produced is less than the energy consumed. These surpluses or deficits appear as net energy gain $(W)$ in the E-PUTs.

The rows of distribution losses $\left(P_{d t}, P_{e t}, P_{i t}, P_{e i t}\right)$ show the distribution losses associated with the fuels used in the energy transformation processes. When the distribution losses cannot be associated with production they are allocated to the final demand $\left(P_{c t}, P_{i c t}\right)$, by using the column "Distribution losses in final demand" (DLFD).

The final demand elements refers to the consumption of energy products by end users of energy, which can be energy domestically produced $\left(F_{d}\right)$ or imported energy $\left(M_{c t}\right)$.

The row and column of totals in the E-PUTs shows the total production of energy by industry and product, and the total final consumption of energy.

The Energy Physical Import Tables (EPIMPs) structure is presented in Figure 2.5, it actually expands into a matrix the information presented in the rows of imported energy in the EPUTs by the different type of fuels used.

The Energy Physical Distribution Losses Tables (EPDLs) structure is presented in Figure 2.6, and similar to the EPIMPs table, it expands the information presented in the rows of distribution losses in the EPUTs by the different type of fuels used. 
Figure 2.3. Structure of Energy Physical Supply Tables - EPSTs

\section{Definitions}

\begin{tabular}{|c|c|c|c|c|}
\hline $\begin{array}{c}\text { IEA } \\
\text { EPST }\end{array}$ & $\begin{array}{c}\text { National Energy } \\
\text { Producing Industries }\end{array}$ & Total Net Energy & Losses & $\begin{array}{c}\text { Total Including } \\
\text { Losses }\end{array}$ \\
\hline $\begin{array}{c}\text { Nergy Products by } \\
\text { Total }\end{array}$ & Supply Table & $\begin{array}{c}\text { Domestic output by } \\
\text { product }\end{array}$ & $\begin{array}{c}\text { Losses on } \\
\text { domestic } \\
\text { production }\end{array}$ & $\begin{array}{c}\text { Domestic output } \\
\text { including losses }\end{array}$ \\
\hline industry & $\begin{array}{c}\text { Total domestic } \\
\text { production of } \\
\text { energy }\end{array}$ & $\begin{array}{c}\text { Total losses on } \\
\text { domestic } \\
\text { production }\end{array}$ & $\begin{array}{c}\text { Total domestic } \\
\text { prod including } \\
\text { losses }\end{array}$ \\
\hline
\end{tabular}

Matrix notation

\begin{tabular}{|c|c|c|c|}
\hline $\begin{array}{c}\text { IEA } \\
\text { EPST }\end{array}$ & $\begin{array}{c}\text { National Energy } \\
\text { Producing Industries }\end{array}$ & Total Net Energy & $\begin{array}{c}\text { Losses } \\
\text { Total Including } \\
\text { Lnergy Products by } \\
\text { National Industries }\end{array}$ \\
\hline Total & $\mathrm{S}$ & $\mathrm{Q}$ & $\mathrm{P}_{\mathrm{f}}$ \\
\hline $\mathrm{X}^{\prime}$ & $\mathrm{X}_{\mathrm{T}}$ & $\mathrm{P}_{\mathrm{ft}}$ & $\mathrm{Q}_{\mathrm{P}}$ \\
\hline
\end{tabular}

Source: Authors' elaboration 
Figure 2.4. Structure of Energy Physical Use Tables - EPUTs

\section{Definitions}

\begin{tabular}{|c|c|c|c|}
\hline $\begin{array}{l}\text { IEA } \\
\text { EPUT }\end{array}$ & $\begin{array}{c}\text { National Energy } \\
\text { Producing Industries }\end{array}$ & Final Demand & Total \\
\hline $\begin{array}{c}\text { Domestically Produced } \\
\text { Energy }\end{array}$ & $\begin{array}{l}\text { Domestically produced } \\
\text { energy used in the } \\
\text { transformation } \\
\text { processes }\end{array}$ & $\begin{array}{c}\text { Final consumption of } \\
\text { domestically produced } \\
\text { energy }\end{array}$ & $\begin{array}{l}\text { Domestic output used } \\
\text { in the transformation } \\
\text { process and in the } \\
\text { final consumption }\end{array}$ \\
\hline $\begin{array}{l}\text { Domestically } \\
\text { Produced Energy } \\
\text { Industry Own Use }\end{array}$ & $\begin{array}{l}\text { Energy industry own } \\
\text { use from domestic } \\
\text { sources }\end{array}$ & Zero & $\begin{array}{l}\text { Domestic output for } \\
\text { energy industry own } \\
\text { use }\end{array}$ \\
\hline \multirow{2}{*}{ Imported Energy } & $\begin{array}{l}\text { Imported energy on } \\
\text { domestic production }\end{array}$ & $\begin{array}{l}\text { Imported energy on } \\
\text { consumption }\end{array}$ & $\begin{array}{l}\text { Imported energy on } \\
\text { production and FD }\end{array}$ \\
\hline & $\begin{array}{l}\text { Imported energy on } \\
\text { industry own use }\end{array}$ & Zero & $\begin{array}{l}\text { Imported energy on } \\
\text { industry on use }\end{array}$ \\
\hline \multirow{4}{*}{ Distribution Losses } & Losses on dom prod & Losses on dom cons & $\begin{array}{l}\text { Total losses on dom } \\
\text { prod and consumption }\end{array}$ \\
\hline & $\begin{array}{c}\text { Losses on industry own } \\
\text { use }\end{array}$ & Zero & $\begin{array}{l}\text { Total losses on } \\
\text { industry own use }\end{array}$ \\
\hline & $\begin{array}{l}\text { Losses on imp dom } \\
\text { prod }\end{array}$ & Losses on imp cons & $\begin{array}{l}\text { Total losses on imp } \\
\text { dom prod and cons }\end{array}$ \\
\hline & $\begin{array}{c}\text { Losses on imp own } \\
\text { use }\end{array}$ & Zero & $\begin{array}{c}\text { Loss on imp industry } \\
\text { own use }\end{array}$ \\
\hline Net Energy Gain & Net Energy Gain & Zero & Total net energy gain \\
\hline Total & $\begin{array}{l}\text { Domestic output by } \\
\text { industry }\end{array}$ & $\begin{array}{c}\text { Final consumption of } \\
\text { energy }\end{array}$ & $\begin{array}{c}\text { Total domestic } \\
\text { production of energy }\end{array}$ \\
\hline
\end{tabular}

Matrix notation

\begin{tabular}{|c|c|c|c|}
\hline $\begin{array}{c}\text { IEA } \\
\text { EPUT }\end{array}$ & $\begin{array}{c}\text { National Energy } \\
\text { Producing Industries }\end{array}$ & Final Demand & Total \\
\hline $\begin{array}{c}\text { Domestically Produced } \\
\text { Energy }\end{array}$ & $\mathrm{U}_{\mathrm{d}}$ & $\mathrm{F}_{\mathrm{d}}$ & $\mathrm{Q}_{\mathrm{d}}$ \\
\hline $\begin{array}{c}\text { Domestically } \\
\text { Produced Energy } \\
\text { Industry Own Use }\end{array}$ & $\mathrm{U}_{\mathrm{e}}$ & Zero & $\mathrm{Q}_{\mathrm{e}}$ \\
\hline \multirow{3}{*}{$\begin{array}{c}\text { Imported Energy } \\
\text { Distribution Losses }\end{array}$} & $\mathrm{M}_{\mathrm{dt}}$ & $\mathrm{M}_{\mathrm{ct}}$ & $\mathrm{M}_{\mathrm{dtt}}$ \\
\cline { 2 - 4 } & $\mathrm{M}_{\mathrm{et}}$ & Zero & $\mathrm{M}_{\mathrm{ett}}$ \\
\cline { 2 - 4 } & $\mathrm{P}_{\mathrm{dt}}$ & $\mathrm{P}_{\mathrm{dct}}$ & $\mathrm{P}_{\mathrm{dtt}}$ \\
\cline { 2 - 4 } & $\mathrm{P}_{\mathrm{et}}$ & Zero & $\mathrm{P}_{\mathrm{ett}}$ \\
\hline Net Energy Gain & $\mathrm{P}_{\mathrm{eit}}$ & $\mathrm{P}_{\mathrm{ict}}$ & $\mathrm{P}_{\mathrm{itt}}$ \\
\hline Total & $\mathrm{W}_{\mathrm{X}}$ & Zero & $\mathrm{P}_{\mathrm{eitt}}$ \\
\hline
\end{tabular}

Source: Authors' elaboration. 
Figure 2.5. Structure of Energy Physical Import Tables - EPIMPs

\section{Definitions}

\begin{tabular}{|c|c|c|c|}
\hline $\begin{array}{c}\text { IEA } \\
\text { EPIMP }\end{array}$ & $\begin{array}{c}\text { National Energy } \\
\text { Producing Industries }\end{array}$ & Final Demand & Total \\
\hline $\begin{array}{c}\text { Imported Energy } \\
\text { Imported energy used } \\
\text { on the transformation } \\
\text { processes }\end{array}$ & $\begin{array}{c}\text { Imported energy on } \\
\text { final consumption }\end{array}$ & $\begin{array}{c}\text { Imported energy used } \\
\text { in the transformation } \\
\text { process and in the } \\
\text { final consumption }\end{array}$ \\
\hline $\begin{array}{c}\text { Imported Energy on } \\
\text { Energy Industry } \\
\text { Own Use }\end{array}$ & $\begin{array}{c}\text { Imported energy used } \\
\text { on energy industry } \\
\text { own use }\end{array}$ & Zero & $\begin{array}{c}\text { Imported energy } \\
\text { industry own use }\end{array}$ \\
\hline Total & $\begin{array}{c}\text { Imported energy by } \\
\text { producing industry }\end{array}$ & $\begin{array}{c}\text { Final consumption of } \\
\text { imported energy }\end{array}$ & Total imported energy \\
\hline
\end{tabular}

Matrix notation

\begin{tabular}{|c|c|c|c|}
\hline $\begin{array}{c}\text { IEA } \\
\text { EPIMP }\end{array}$ & $\begin{array}{c}\text { National Energy } \\
\text { Producing Industries }\end{array}$ & Final Demand & Total \\
\hline Imported Energy & $\mathrm{M}_{\mathrm{d}}$ & $\mathrm{M}_{\mathrm{c}}$ & $\mathrm{M}_{\mathrm{df}}$ \\
\hline $\begin{array}{c}\text { Imported Energy on } \\
\text { Energy Industry } \\
\text { Own Use }\end{array}$ & $\mathrm{M}_{\mathrm{e}}$ & Zero & $\mathrm{M}_{\mathrm{ef}}$ \\
\hline Total & $\mathrm{M}_{\mathrm{dt}}$ & $\mathrm{M}_{\mathrm{ct}}$ & $\mathrm{M}_{\mathrm{tt}}$ \\
\hline
\end{tabular}

Source: Authors' elaboration 
Figure 2.6. Structure of Energy Physical Distribution Losses Tables - EPDLs

Definitions

\begin{tabular}{|c|c|c|c|}
\hline $\begin{array}{l}\text { IEA } \\
\text { EPDL }\end{array}$ & $\begin{array}{c}\text { National Energy } \\
\text { Producing Industries }\end{array}$ & Final Demand & Total \\
\hline $\begin{array}{c}\text { Distribution Losses on } \\
\text { Domestically Produced } \\
\text { Energy }\end{array}$ & $\begin{array}{c}\text { Distribution losses on } \\
\text { the transformation } \\
\text { processes }\end{array}$ & $\begin{array}{l}\text { Distribution losses on } \\
\text { the final consumption }\end{array}$ & $\begin{array}{l}\text { Losses in the } \\
\text { transformation } \\
\text { process and in the } \\
\text { final consumption }\end{array}$ \\
\hline $\begin{array}{c}\text { Distribution Losses on } \\
\text { Energy Industry } \\
\text { Own Use }\end{array}$ & $\begin{array}{c}\text { Distribution losses on } \\
\text { domestic energy } \\
\text { industry own use }\end{array}$ & Zero & $\begin{array}{l}\text { Losses on energy } \\
\text { industry own use }\end{array}$ \\
\hline $\begin{array}{l}\text { Distribution Losses on } \\
\text { Imports for Domestic } \\
\text { Production }\end{array}$ & $\begin{array}{c}\text { Distribution losses on } \\
\text { imported energy used } \\
\text { in the transformation } \\
\text { processes }\end{array}$ & $\begin{array}{c}\text { Distribution losses on } \\
\text { imported energy used } \\
\text { in final consumption }\end{array}$ & $\begin{array}{l}\text { Losses on imports in } \\
\text { the transformation } \\
\text { process and in final } \\
\text { consumption }\end{array}$ \\
\hline $\begin{array}{l}\text { Distribution Losses on } \\
\text { Imports for Energy } \\
\text { Industry Own Use }\end{array}$ & $\begin{array}{l}\text { Distribution losses on } \\
\text { imported energy for } \\
\text { industry own use }\end{array}$ & Zero & $\begin{array}{c}\text { Losses on imports for } \\
\text { energy industry own } \\
\text { use }\end{array}$ \\
\hline Total & $\begin{array}{l}\text { Distribution losses by } \\
\text { producing industry }\end{array}$ & $\begin{array}{l}\text { Distribution losses on } \\
\text { final consumption }\end{array}$ & $\begin{array}{c}\text { Total distribution } \\
\text { losses }\end{array}$ \\
\hline
\end{tabular}

Matrix notation

\begin{tabular}{|c|c|c|c|}
\hline $\begin{array}{c}\text { IEA } \\
\text { EPDL }\end{array}$ & $\begin{array}{c}\text { National Energy } \\
\text { Producing Industries }\end{array}$ & Final Demand & Total \\
\hline $\begin{array}{c}\text { Distribution Losses on } \\
\text { Domestically Produced } \\
\text { Energy }\end{array}$ & $\mathrm{P}_{\mathrm{d}}$ & $\mathrm{P}_{\mathrm{dc}}$ & $\mathrm{P}_{\mathrm{df}}$ \\
\hline $\begin{array}{c}\text { Distribution Losses on } \\
\text { Energy Industry } \\
\text { Own Use }\end{array}$ & $\mathrm{P}_{\mathrm{e}}$ & Zero & $\mathrm{P}_{\mathrm{ef}}$ \\
\hline $\begin{array}{c}\text { Distribution Losses on } \\
\text { Imports for Domestic } \\
\text { Production }\end{array}$ & $\mathrm{P}_{\mathrm{i}}$ & $\mathrm{P}_{\mathrm{ic}}$ & $\mathrm{P}_{\text {if }}$ \\
\hline $\begin{array}{c}\text { Distribution Losses on } \\
\text { Imports for Energy } \\
\text { Industry Own Use }\end{array}$ & $\mathrm{P}_{\mathrm{ei}}$ & $\mathrm{ZerO}_{\mathrm{ft}}$ & $\mathrm{P}_{\mathrm{eif}}$ \\
\hline Total & $\mathrm{P}_{\mathrm{t}}$ & $\mathrm{P}_{\mathrm{ct}}$ & $\mathrm{P}_{\mathrm{tt}}$ \\
\hline
\end{tabular}

Source: Authors' elaboration. 
Table 2.4. Matrices and Dimensions

\begin{tabular}{|c|c|c|}
\hline Variable & Dimension & Description \\
\hline$m$ & & Number of energy products \\
\hline$n$ & & Number of energy industries \\
\hline$k$ & & Number of final demand elements \\
\hline$F_{d}$ & $m \times k$ & Final consumption of domestically produced energy \\
\hline$F_{T T}$ & $1 \times k$ & Total consumption of energy by the final demand \\
\hline$M_{c}$ & $m \times k$ & Imported energy on final consumption \\
\hline$M_{c t}$ & $1 \times k$ & Imported energy used in final consumption \\
\hline$M_{d}$ & $m \times n$ & Imported energy used in the transformation processes \\
\hline$M_{d f}$ & $m \times 1$ & $\begin{array}{l}\text { Imported energy used in the transformation process and in the final consumption, by type of } \\
\text { product }\end{array}$ \\
\hline$M_{d t}$ & $1 \times n$ & Imported energy used on domestic production \\
\hline Mdtt & $1 \times 1$ & Total imported energy used in the transformation process and in final consumption \\
\hline$M_{e}$ & $m \times n$ & Imported energy on industry own use by energy product and industry \\
\hline Mef & $m \times 1$ & Imported energy on industry own use by product \\
\hline$M_{e t}$ & $1 \times n$ & Imported energy on industry own use by industry \\
\hline$M_{e t t}$ & $1 \times 1$ & Total imported energy on industry own use \\
\hline$M_{t t}$ & $1 \times 1$ & Total imported energy \\
\hline$P_{c t}$ & $1 \times k$ & Losses on domestic energy used in final consumption \\
\hline$P_{d}$ & $m \times n$ & Losses on energy used in the transformation processes \\
\hline$P_{d c}$ & $m \times k$ & Losses on the final consumption by type of product \\
\hline$P d c t$ & $1 \times k$ & Losses on the final consumption \\
\hline$P_{d f}$ & $m \times 1$ & Losses in the transformation process and in the final consumption \\
\hline$P_{d t}$ & $1 \times n$ & Losses on domestic production \\
\hline$P_{d t t}$ & $1 \times 1$ & Total losses on energy used in the transformation process and in final consumption \\
\hline$P_{e}$ & $m \times n$ & Losses on domestic energy industry own use \\
\hline$P_{e f}$ & $m \times 1$ & Losses on energy industry own use \\
\hline$P_{e i}$ & $m \times n$ & Losses on imported energy for industry own use \\
\hline$P_{\text {eif }}$ & $m \times 1$ & Losses on imports for energy industry own use \\
\hline$P_{\text {eit }}$ & $1 \times n$ & Losses on imports used on industry own use \\
\hline$P_{\text {eitt }}$ & $1 \times 1$ & Total losses on imported energy used on industry own use \\
\hline Pet & $1 \times n$ & Losses on industry own use \\
\hline$P_{\text {ett }}$ & $1 \times 1$ & Total energy losses on industry own use \\
\hline$P_{f}$ & $m \times 1$ & Losses on domestic production \\
\hline$P_{f t}$ & $1 \times 1$ & Total losses on domestic production \\
\hline$P_{i}$ & $m \times n$ & Losses on imported energy used in the transformation processes \\
\hline$P_{i c}$ & $m \times k$ & Losses on imported energy used in final consumption by type of product \\
\hline$P_{\text {ict }}$ & $1 \times k$ & Losses on imported energy used in final consumption \\
\hline
\end{tabular}

Continued ... 
Table 2.4 Matrices and Dimensions (Continued)

\begin{tabular}{l|l|l}
\hline Variable & Dimension & Description \\
\hline$P_{i f}$ & $m \times 1$ & Losses on imports in the transformation process and in final consumption \\
\hline$P_{i t}$ & $1 \times n$ & Losses on imports used in the domestic production \\
\hline$P_{i t t}$ & $1 \times 1$ & Total losses on imported energy used in the transformation process and in final consumption \\
\hline$P_{t}$ & $n \times 1$ & Total losses by producing industry \\
\hline$P_{t t}$ & $1 \times 1$ & Total distribution losses \\
\hline$Q$ & $m \times 1$ & Domestic energy produced, by type of product \\
\hline$Q_{d}$ & $m \times 1$ & $\begin{array}{l}\text { Domestic output used in the transformation process and in the final consumption, by type of } \\
\text { product }\end{array}$ \\
\hline$Q_{e}$ & $m \times 1$ & Domestic output for energy industry own use, by type of product \\
\hline$Q_{p}$ & $m \times 1$ & Domestic energy produced, by type of product, including losses \\
\hline$S$ & $m \times n$ & Supply table \\
\hline$U_{d}$ & $m \times n$ & Domestically produced energy used in the transformation processes \\
\hline$U_{e}$ & $m \times n$ & Energy industry own use from domestic sources \\
\hline$W$ & $1 \times n$ & Net energy gain \\
\hline$W_{T}$ & $1 \times 1$ & Total net energy gain \\
\hline$X$ & $n \times 1$ & Domestic output by industry \\
\hline$X_{T}$ & $1 \times 1$ & Total domestic production of energy \\
\hline$X_{T P}$ & $1 \times 1$ & Total domestic production of energy including losses \\
\hline
\end{tabular}

Taking into consideration the above overview of the WEBs and E-PSUTs, we turn now to the methodology used to estimate the E-PSUTs from WEBs (Figure 2.1). The allocation of values from the WEBs to the E-PSUTs requires the following steps:

1. Transformation process:

a. Positive values are considered as energy output and are allocated to the Supply table $(S)$ according to the fuel transformation process and fuel type;

b. The negative values in the transformation process are multiplied by -1 to be considered as positive values, and allocated as fuels inputs in the fuels production process in matrix $U_{d}$. 
2. Energy industry own use:

a. The following energy own industries are directly associated with the fuel transformation process and are considered as only one fuel transformation process:
i. MAINELEC $=$ MAINELEC + EPUMPST
ii. $\quad$ TBLASTFUR $=$ TBLASTFUR + EBLASTFUR
iii. $\quad$ TGASWKS $=$ TGASWKS + EGASWKS
iv. $\quad$ TCOKEOVS $=$ TCOKEOVS + ECOKEOVS
v. TPATFUEL $=$ TPATFUEL + EPATFUEL
vi. $\quad \mathrm{TBKB}=\mathrm{TBKB}+\mathrm{EBKB}$
vii. $\quad$ TREFINER $=$ TREFINER + EREFINER
viii. TCOALLIQ $=$ TCOALLIQ + ECOALLIQ
ix. $\quad$ TGTL $=$ TGTL + EGTL
x. TCHARCOAL $=$ TCHARCOAL + ECHARCOAL

b. The values of EPWPLT are allocated to the following fuel production processes according the share of each process in the sum of the energy they produce: MAINELEC, AUTOELEC, MAINCHP, AUTOCHP, MAINHEAT and AUTOHEAT;

c. The values of ENONSPEC are split proportionally between all the energy transformation/production processes that use the same fuels as the ones used by ENONSPEC;

d. The following energy industry own use are considered individually as being fuels production processes:
i. MINES_PRIMARY $=$ MINES_PRIMARY + EMINES
ii. OILGASEX_PRIMARY = OILGASEX_PRIMARY + EOILGASEX
iii. BIOGAS_PRIMARY $=$ BIOGAS_PRIMARY + EBIOGAS
iv. NUCLEAR_PRIMARY $=$ NUCLEAR_PRIMARY + ENUC;

e. ELNG is added to distribution losses and it is treated as such;

f. The values are multiplied by -1 to become positive numbers;

g. The values are allocated as inputs in the fuel production process in matrix $U_{e}$.

3. Total final consumption:

a. The values are allocated to the final consumption matrix $\left(F_{d}\right)$.

4. Marine and aviation bunkers, exports, stock changes, transfers, statistical differences

a. The values are multiplied by -1 ;

b. The values are allocated to the final consumption matrix $\left(F_{d}\right)$. 
5. Imports and distribution losses:

a. As the products of energy used in the TIC and TFC accounts of the energy balance includes imports and distribution losses, they need to be explicitly adjusted in these accounts and allocated, respectively, to the import matrices $\left(M_{d}, M_{e}, M_{c}\right)$ and to the industry distribution losses matrices $\left(P_{i}, P_{e i}\right)$. When the distribution losses cannot be associated with production, they are allocated to final consumption $\left(P_{i c}\right)$.

6. Imports:

a. The allocation of imported fuel to the imported matrices assumes that the share of imports in a given consumed fuel is the same in all the end users of this fuel and is given by the share of this imported fuel in the total use of this fuel;

b. The imported values allocated to the import matrices $\left(M_{d}, M_{e}, M_{c}\right)$ are subtracted from the energy previously allocated to the domestic matrices ( $U_{d}$, $\left.U_{e}, F_{d}\right)$;

c. For the allocation of imports to the final demand components, a specific approach is required for stock changes, transfers and statistical differences. The imported values are allocated to stock changes only if there is an increase in the stocks; the values are allocated to transfers and statistical differences only if the subtraction of imports from the consumption of a fuel generates negative values in the consumption of this fuel.

7. Distribution losses:

a. The values of distribution losses are multiplied by -1 ;

b. The procedure to estimate the distribution losses $\left(P_{d}, P_{e}, P_{i}, P_{e i}\right)$ is to estimate the energy lost from the use of this energy, either domestic or imported, in the matrices of intermediate use $\left(U_{d}, U_{e}, M_{d}, M_{e}\right)$;

c. The allocation of the distribution losses assumes that the share of distribution losses in a given consumed fuel is the same in all the end users of this fuel and is given by the share of this distribution losses in the total use of this fuel;

d. In the cases where the value of the distribution losses are greater than the total value of a fuel used in the energy transformation process, there is an adjustment, so that the inputted energy values remains greater or equal to zero, and the difference of the distribution losses for this fuel is allocated to final demand $\left(P_{d c}, P_{i c}\right)$. 
8. Matrices of totals by domestic and imported fuel $\left(Q_{d}, Q_{e}, M_{d t}, M_{e t}, Q\right)$ :

a. By using the information on the consumption of domestic energy and imported energy it possible to obtain the fuel totals that are domestically produced and imported:

i. The sum over each row of $U_{d}$ plus the sum over each row of $F_{d}$ will give $Q_{d}$;

ii. The sum over each row of $U_{e}$ will give $Q_{e}$;

iii. The sum over each row of $M_{d}$ plus the sum over each row of $M_{c}$ will give Mdf ;

iv. The sum over each row of $M_{e}$ will give $M_{e f}$;

v. The sum of $Q_{d}$ and $M d f$ will give $Q$.

9. Supply table $(S)$ :

a. The production of domestic fuels obtained from the outputs of the transformation process (item 1.a) is allocated to the supply table;

b. The indigenous production (INDPROD) in the WEB is allocated to the supply table according to the distribution table presented in Annex A;

c. The values for NATGAS, NONCRUDE and HEAT from item (a) are allocated as secondary energy (NATGAS_S, NONCRUDE_S and HEAT_S), while the values from item (b) are allocated as primary energy (NATGAS_P, NONCRUDE_P and HEAT_P);

d. The values in the supply table are adjusted to reflect the net supplied energy, i.e., energy net of distribution losses;

e. The distribution losses on the domestically produced energy are allocated to the column distribution losses in the supply table $\left(P_{f}\right)$.

10. Domestic output by fuel processing process $(X)$ :

a. The sum over each column of the supply table $(S)$ will give the domestic output of the fuel production processes $(X)$.

11. Net energy gain $(W)$ :

a. The estimated net energy gain $(W)$ is obtained by subtracting from the domestic output of the fuel processing processes $(X)$ the values of the intermediate inputs used in production $\left(U_{d}, U_{e}, M_{d t}, U_{e t}, P_{d t}, P_{e t}, P_{i t}, P_{e i t}\right)$.

\subsection{Example of an EPSUT}

Based on Figure 2.3 and Figure 2.4, this section presents an example of an Energy Physical Supply (EPST) and the Use (EPUT) Table.

The Energy Physical Supply Table (EPST) shows the amount of fuels produced by each industry. In the example, the economy has five fuel industries (Mines primary, Oil and gas primary, Electricity primary, Oil refineries, and Electricity Plants) and six energy goods (Coal, Crude oil and gas, Diesel, Other Fuels, Hydro and nuclear electricity, and Electricity and heat). Oil refineries produces two types of fuels (Diesel and Other fuels), while the other five industries produce only one kind of fuel each. Four of the fuels 
considered are produced by only one industry, while other fuels are produced by Oil refineries. The only fuel which shows distribution losses is Electricity and heat, the losses on this domestic produced fuel are 20 units of energy, meaning that the fuel available for consumption is 360 units (net output) and the total output is 380 units.

In the Energy Physical Use Table (EPUT), the fuels produced can be consumed by the fuel industries to produce energy, used by the non-energy industries to produce goods and services, used by households and for the transportation of goods and services, or exported. The fuels used to produce energy are referred to as intermediate inputs, while the fuels used for other purposes are referred as final fuel consumption, and are considered in the final demand for energy. For example, coal can be used: a) to generate energy in the Mines primary, as own energy use; b) used in electricity plants as fuel to produce energy (intermediate inputs); c) used in the iron and steel industry to produce iron and steel (final fuel consumption); d) or exported.

Besides the fuels produced domestically, imported fuels can also be used in the production of energy or directly used by the final consumers. This is shown in the row of Imports.

The distribution losses incurred in transformation process are shown in the row of Distribution losses.

Electricity primary, which produces hydro and nuclear electricity, uses no energy inputs, and all of its production is allocated to Electricity plants, which then distributes this energy to the consumers.

Electricity plants, which produces Electricity and heat uses domestic and imported inputs in its production. Also, note that besides hydro and nuclear electricity, which is directly allocated to this industry, coal, and crude oil and gas, are the most important inputs. In this example, Electricity plants uses 309 units of coal and 215 units of crude oil and gas from domestic origin. The total energy consumed by Electricity plants is 881 units, 838 units used as fuel to produce energy, zero units used as own energy, 30 units of imported energy, and 13 units of distribution losses. It produces 360 units to supply the needs of the economy, showing a net use of 521 units of energy in the production process. These differences in energy requirements for production are reflected in the net energy gain account, where the numbers show the balance of energy required to produce usable energy. The net energy gain will be positive for industries which produces primary energy (coal, oil, nuclear, hydro, wind, solar, etc.), and usually negative for other industries.

In the case of the Oil refineries industry, 939 units of energy are used to produce 850 units; 459 units used as fuel to produce energy, 56 units used as own energy, 420 units of imported energy, and 4 units of distribution losses.

A link can be made between the Net Energy Gain (NEG) and the final fuel consumption. In the example, the net energy gain is 1104 units while the total domestic energy, including the foreign intermediate inputs, used by final demand is 1579 units. The difference of 475 units refers to the imported energy and distribution losses associated with production of the national energy industries and embodied in the final demand energy, i.e.:

$\mathrm{NEG}=\mathrm{FD}$ of domestic energy - Intermediate imported energy - Distribution losses 
Figure 2.7. Energy physical supply and use tables, an example

\begin{tabular}{|c|c|c|c|c|c|c|c|c|c|}
\hline \multicolumn{10}{|c|}{ ENERGY PHYSICAL SUPPLY TABLE } \\
\hline & & \multicolumn{5}{|c|}{ NATIONAL INDUSTRY } & \multirow[b]{2}{*}{$\begin{array}{l}\text { TOTAL Net } \\
\text { Energy }\end{array}$} & \multirow[b]{2}{*}{$\begin{array}{c}\text { Distribution } \\
\text { Losses }\end{array}$} & \multirow{2}{*}{$\begin{array}{c}\text { TOTAL } \\
\text { Including } \\
\text { Losses }\end{array}$} \\
\hline & & Mines primary & $\begin{array}{l}\text { Oil and gas } \\
\text { primary }\end{array}$ & $\begin{array}{l}\text { Electricity } \\
\text { primary }\end{array}$ & Oil refineries & Electricity plants & & & \\
\hline \multirow{6}{*}{$\begin{array}{c}\text { ENERGY } \\
\text { PRODUCTS } \\
\text { MADE BY } \\
\text { NATIONAL } \\
\text { INDUSTRIES }\end{array}$} & Toal & 350 & 0 & 0 & 0 & 0 & 350 & & $--=-\frac{-1}{350}$ \\
\hline & \begin{tabular}{|l} 
Crude oil and gas \\
\end{tabular} & 0 & 1,150 & 0 & 0 & 0 & 1,150 & 0 & 1,150 \\
\hline & \begin{tabular}{|l|l|} 
Diesel \\
\end{tabular} & 0 & 0 & 0 & 230 & 0 & 230 & & 230 \\
\hline & \begin{tabular}{|l} 
Other Fuels \\
\end{tabular} & 0 & 0 & 0 & 620 & 0 & 620 & & 620 \\
\hline & Hydro \& Nuclear electricity & 0 & 0 & 270 & 0 & 0 & 270 & & 270 \\
\hline & Electricity and Heat & 0 & 0 & 0 & 0 & 360 & 360 & & 380 \\
\hline & TOTAL & 350 & 1,150 & 270 & 850 & 360 & 2,980 & 20 & 3,0007 \\
\hline
\end{tabular}

\begin{tabular}{|c|c|c|c|c|c|c|c|c|c|c|}
\hline \multicolumn{11}{|c|}{ ENERGY PHYSICAL USE TABLE } \\
\hline & & \multicolumn{5}{|c|}{ NATIONAL ENERGY INDUSTRIES } & \multicolumn{3}{|c|}{ Final Demand } & \multirow[b]{2}{*}{ TOTAL } \\
\hline & & Mines primary & $\begin{array}{c}\text { Oil and gas } \\
\text { primary }\end{array}$ & $\begin{array}{c}\begin{array}{c}\text { Electricity } \\
\text { primary }\end{array} \\
\end{array}$ & Oil refineries & Electricity plants & Industries & \begin{tabular}{|c|} 
Households \\
and Transport
\end{tabular} & Exports & \\
\hline \multirow{6}{*}{ 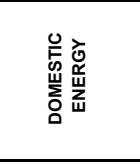 } & Coal & 0 & 0 & 0 & 0 & 309 & 10 & 0 & 30 & 349 \\
\hline & \begin{tabular}{|c|} 
Crude oil and gas \\
\end{tabular} & 0 & 0 & 0 & 450 & 215 & 210 & 125 & 96 & 1,096 \\
\hline & Diesel & 0 & 0 & 0 & 5 & 4 & 35 & 125 & 55 & 224 \\
\hline & Other Fuels & 0 & 0 & 0 & 4 & 20 & 135 & 305 & 125 & 589 \\
\hline & Hydro \& Nuclear electricity & 0 & 0 & 0 & 0 & 270 & 0 & 0 & 0 & 270 \\
\hline & Electricity and Heat & 0 & 0 & 0 & 0 & 20 & 196 & 130 & 2 & 348 \\
\hline \multirow{6}{*}{ 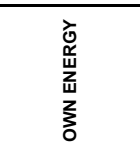 } & Coal & 1 & 0 & 0 & 0 & 0 & 0 & 0 & 0 & 1 \\
\hline & Crude oil and gas & 0 & 34 & 0 & 20 & 0 & 0 & 0 & 0 & 54 \\
\hline & \begin{tabular}{|l|} 
Diesel \\
\end{tabular} & 2 & 4 & 0 & 0 & 0 & 0 & 0 & 0 & 6 \\
\hline & \begin{tabular}{|l|} 
Other Fuels \\
\end{tabular} & 0 & 1 & 0 & 30 & 0 & 0 & 0 & 0 & 31 \\
\hline & Hydro \& Nuclear electricity & 0 & 0 & 0 & 0 & 0 & 0 & 0 & 0 & 0 \\
\hline & Electricity and Heat & 2 & 4 & 0 & 6 & 0 & 0 & 0 & 0 & 12 \\
\hline IMPORTS & Imports & 1 & 4 & 0 & 420 & 30 & 36 & 65 & 45 & 601 \\
\hline \begin{tabular}{|l|} 
DIST. LOSSES \\
\end{tabular} & Distribution losses & 1 & 2 & 0 & 4 & 13 & 0 & 0 & 0 & 20 \\
\hline NET ENERGY GAIN & NEG & 343 & 1,101 & 270 & -89 & -521 & & & & 1,104 \\
\hline & TOTAL & 350 & 1,150 & 270 & 850 & 360 & 622 & 750 & 353 & \\
\hline
\end{tabular}

Source: Authors' elaboration 


\section{Final Comments}

This paper presented the methodology used for the estimation of EPSUTs based on IEA's WEB. The estimated EPSUTs should be viewed as an important step to study and better understand the interconnections of energy production with the world economy and the emissions associated with fuel combustion.

A first set of indicators, based on the EPSUTs, will explore the distinction between primary versus secondary energy, and the requirements of energy to produce energy. A further step of these indicators would be to estimate direct versus indirect energy through a link to national input-output models, so-called "lifecycle energy indicators".

More complex indicators, can be obtained by combining the EPSUTs with the ICIO tables estimated by OECD, in an Energy MF-IO hybrid model. Such indicators associate energy use with monetary production and consumption of goods and services around the world. Based on these indicators, it will be possible to measure the importance of countries for energy production and consumption in the world. A natural extension of these energy indicators would be to obtain improved estimates of embodied carbon indicators, by fuel type, using the relevant emission factors estimated by IEA.

The estimation and use of EPSUTs and related indicators can also contribute to data quality assurance, highlighting to countries included in the IEA-WEB database the importance of supplying a consistent set of energy data to IEA. Despite the efforts of IEA to assure the consistency of the WEB, this database sometimes suffers from lack of information, or a high level of data aggregation submitted to IEA by some countries.

The development of novel energy-use indicators, providing a richer understanding of the multiple links between global energy systems and the global economy has the potential to make an important contribution to ongoing discussions related to climate change, notably through OECD's International Programme for Action on Climate (IPAC) initiative. 


\section{Endnotes}

${ }^{1}$ The authors would like to thank the following colleagues for their comments that helped improve this paper: Andrew Wyckoff, Dirk Pilat, Sarah Box, Rodolfo Ostolaza, Carmen Zürcher, Angelita Ruvalcaba, Ali Alsamawi and Norihiko Yamano.

${ }^{2}$ https://www.iea.org/reports/world-energy-balances-overview

${ }^{3}$ http://oe.cd/icio

${ }^{4}$ The territorial and residential principal, as presented in the System of National Accounts (SNA), will be dealt in the MF-IO hybrid model. 


\section{References}

Guevara, Z. and T. Domingos (2017) "The multi-factor energy input-output model", Energy Economics, 61, pp. 261-269.

Heun, M.K., A. Owen, and P.E. Brockway (2018) "A physical supply-use table framework for energy analysis on the energy conversion chain", Applied Energy, 226, pp. 1134-1162.

IEA (2020) World Energy Balances 2020 Edition: Database Documentation, International Energy Agency.

Miller, M. and P. Blair (2009) Input-Output Analysis: Foundations and Extensions. $2^{\text {nd }}$ edition. Cambridge: Cambridge University Press.

UN (2016) System of Environmental Economic Accounts (SEEA) Technical Note: Energy Accounting, United Nations.

UN (2019) System of Environmental Economic Accounting for Energy (SEEA-Energy), Department of Economic and Social Affairs: Statistics Division, Studies in Methods Series F No. 116. United Nations. ISBN 978-92-1-161623-1.

Wyckoff, A.W., L.S. Johns, P.D. Blair, S.D. Casler (1990). Energy Use and the U.S. Economy. U.S. Congress, Office of Technology Assessment, OTA-BP-E-57 (Washington, DC: U.S. Government Printing Office, June). 


\section{Annex A. Appendix}

Figure A.1. Map of fuel production processes to fuels production

\begin{tabular}{|c|c|c|c|c|c|c|c|c|c|c|c|c|c|c|c|c|c|c|c|c|c|c|c|c|c|c|c|c|c|c|c|c|}
\hline \multirow{2}{*}{\multicolumn{2}{|c|}{ INDUSTRIES }} & \multicolumn{31}{|c|}{ PRIMARY } \\
\hline & & 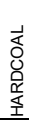 & $\begin{array}{l}z \\
0 \\
\frac{\alpha}{0} \\
\frac{\alpha}{\infty}\end{array}$ & 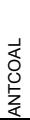 & $\begin{array}{l}\vec{\delta} \\
\text { ठ } \\
\text { ठे } \\
\end{array}$ & $\begin{array}{l}\vec{J} \\
\text { ठ̀ } \\
\frac{\hat{t}}{\omega}\end{array}$ & 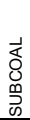 & 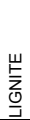 & $\underset{⿱ 亠 凶}{\stackrel{\leftarrow}{a}}$ & 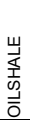 & 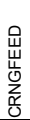 & 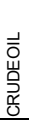 & $\stackrel{d}{\underline{z}}$ & 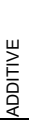 & 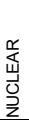 & $\begin{array}{l}\text { o } \\
\text { ò } \\
\text { a }\end{array}$ & 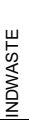 & 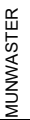 & 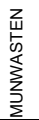 & 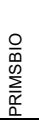 & 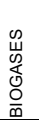 & 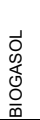 & 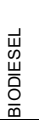 & 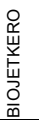 & $\begin{array}{l}\frac{o}{\vec{J}} \\
\frac{0}{0} \\
\end{array}$ & 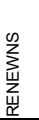 & 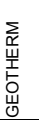 & 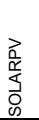 & $\begin{array}{l}\text { I } \\
\text { 竞 } \\
\text { O } \\
\text { O) }\end{array}$ & 㸃 & $\sum_{j}^{0}$ & 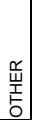 \\
\hline \multirow{14}{*}{ 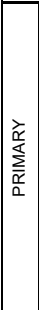 } & MINES_PRIMARY & $\frac{\Delta}{1}$ & $\frac{w}{1}$ & $\frac{x}{1}$ & 1 & $\frac{w}{1}$ & 1 & $\overrightarrow{1}$ & $\frac{w}{1}$ & 0 & 0 & 0 & 0 & $\frac{x}{0}$ & 0 & 0 & $\overline{0}$ & 0 & 0 & $\frac{\omega}{0}$ & 0 & 0 & 0 & 0 & 0 & 0 & 0 & 0 & 0 & 0 & 0 & 0 \\
\hline & OILGASEX_PRIMARY & 0 & 0 & 0 & 0 & 0 & 0 & 0 & 0 & 1 & 1 & 1 & 1 & 1 & 0 & 0 & 0 & 0 & 0 & 0 & 0 & 0 & 0 & 0 & 0 & 0 & 0 & 0 & 0 & 0 & & 0 \\
\hline & NUCLEAR_PRIMARY & 0 & 0 & 0 & 0 & 0 & 0 & 0 & 0 & 0 & 0 & 0 & 0 & 0 & 1 & 0 & 0 & 0 & 0 & 0 & 0 & 0 & 0 & 0 & 0 & 0 & 0 & 0 & 0 & 0 & & \\
\hline & HYDRO_PRIMARY & 0 & 0 & 0 & 0 & 0 & 0 & 0 & 0 & 0 & 0 & 0 & 0 & 0 & 0 & 1 & 0 & 0 & 0 & 0 & 0 & 0 & 0 & 0 & 0 & 0 & 0 & 0 & 0 & 0 & 0 & 0 \\
\hline & WASTE_PRIMARY & 0 & 0 & 0 & 0 & 0 & 0 & 0 & 0 & 0 & 0 & 0 & 0 & 0 & 0 & 0 & 1 & 1 & 1 & 0 & 0 & 0 & 0 & 0 & 0 & 0 & 0 & 0 & 0 & 0 & 0 & 0 \\
\hline & BIOGAS_PRIMARY & 0 & 0 & 0 & 0 & 0 & 0 & 0 & 0 & 0 & 0 & 0 & 0 & 0 & 0 & 0 & 0 & 0 & 0 & 0 & 1 & 0 & 0 & 0 & 0 & 0 & 0 & 0 & 0 & 0 & & \\
\hline & BIOLIQ_PRIMARY & 0 & 0 & 0 & 0 & 0 & 0 & 0 & 0 & 0 & 0 & 0 & 0 & 0 & 0 & 0 & 0 & 0 & 0 & 0 & 0 & 1 & 1 & 1 & 1 & 0 & 0 & 0 & 0 & 0 & 0 & 0 \\
\hline & BIOMASS_PRIMARY & 0 & 0 & 0 & 0 & 0 & 0 & 0 & 0 & 0 & 0 & 0 & 0 & 0 & 0 & 0 & 0 & 0 & 0 & 1 & 0 & 0 & 0 & 0 & 0 & 0 & 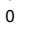 & 0 & 0 & 0 & 0 & 0 \\
\hline & BIONS_PRIMARY & 0 & 0 & 0 & 0 & 0 & 0 & 0 & 0 & 0 & 0 & 0 & 0 & 0 & 0 & 0 & 0 & 0 & 0 & 0 & 0 & 0 & 0 & 0 & 0 & 1 & 0 & 0 & 0 & 0 & 0 & 0 \\
\hline & GEOTHERMAL_PRIMARY & 0 & 0 & 0 & 0 & 0 & 0 & 0 & 0 & 0 & 0 & 0 & 0 & 0 & 0 & 0 & 0 & 0 & 0 & 0 & 0 & 0 & 0 & 0 & 0 & 0 & 1 & 0 & 0 & 0 & 0 & 0 \\
\hline & REN_ELE_PRIMARY & 0 & 0 & 0 & 0 & 0 & 0 & 0 & 0 & 0 & 0 & 0 & 0 & 0 & 0 & 0 & 0 & 0 & 0 & 0 & 0 & 0 & 0 & 0 & 0 & 0 & 0 & 1 & 0 & 1 & 1 & 0 \\
\hline & REN_HEAT_PRIMARY & 0 & 0 & 0 & 0 & 0 & 0 & 0 & 0 & 0 & 0 & 0 & 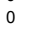 & 0 & 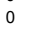 & 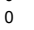 & 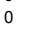 & 0 & 0 & 0 & 0 & 0 & 0 & 0 & 0 & 0 & 0 & 0 & 1 & 0 & 0 & 0 \\
\hline & NONCRUDE_PRIMARY & 0 & 0 & 0 & 0 & 0 & 0 & 0 & 0 & 0 & 0 & 0 & 0 & 0 & 0 & 0 & 0 & 0 & 0 & 0 & 0 & 0 & 0 & 0 & 0 & 0 & 0 & 0 & 0 & 0 & & 0 \\
\hline & OTHER_PRIMARY & 0 & 0 & 0 & 0 & - & 0 & - & 0 & 0 & 0 & 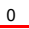 & 0 & 0 & 0 & 0 & 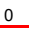 & 0 & 0 & - & - & 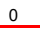 & 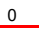 & $=$ & - & 0 & 0 & 0 & 0 & 0 & 0 & 1 \\
\hline \multirow{21}{*}{ 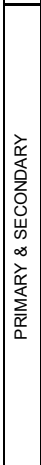 } & MAINELEC & 0 & 0 & 0 & 0 & 0 & 0 & 0 & 0 & 0 & 0 & 0 & 0 & 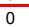 & 0 & 0 & 0 & 0 & 0 & 0 & 0 & 0 & 0 & 0 & 0 & 0 & 0 & 0 & 0 & 0 & 0 & 0 \\
\hline & AUTOELEC & 0 & 0 & 0 & 0 & 0 & 0 & 0 & 0 & 0 & 0 & 0 & 0 & 0 & 0 & 0 & 0 & $\mathrm{C}^{2}+2$ & 0 & 0 & 0 & 0 & 0 & 0 & 0 & 0 & 0 & 0 & 0 & 0 & 0 & 0 \\
\hline & MAINCHP & 0 & 0 & 0 & 0 & 0 & 0 & 0 & 0 & 0 & 0 & 0 & 0 & 0 & 0 & 年 & 0 & 0 & 0 & 0 & 0 & 0 & 0 & 0 & 0 & 0 & 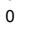 & 0 & 0 & 0 & 0 & 0 \\
\hline & AUTOCHP & 0 & 0 & 0 & 0 & 0 & 0 & 0 & 0 & 0 & 0 & 0 & 0 & 0 & 0 & 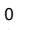 & 0 & 0 & 0 & 0 & 0 & 0 & 0 & 0 & 0 & 0 & 0 & 0 & 0 & 0 & 0 & 0 \\
\hline & MAINHEAT & 0 & 0 & 0 & 0 & 0 & 0 & 0 & 0 & 0 & 0 & 0 & 0 & 0 & 政 & 0 & 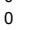 & 0 & 0 & 0 & 0 & 0 & 0 & 0 & 0 & 0 & 0 & 0 & 0 & 0 & 0 & 0 \\
\hline & AUTOHEAT & 0 & 0 & 0 & 0 & 0 & 0 & 0 & 0 & 0 & 0 & 0 & 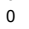 & 年 & 0 & 0 & 0 & 0 & ( & S & 0 & 0 & v & 0 & 0 & 0 & 0 & 0 & 0 & 0 & & 0 \\
\hline & THEAT & 0 & 0 & 0 & 0 & 0 & 0 & 0 & 0 & 0 & 0 & 0 & 0 & 0 & 0 & 0 & 0 & 0 & 0 & 0 & 0 & 0 & 0 & 0 & 0 & 0 & 0 & 0 & 0 & 0 & 0 & 0 \\
\hline & TBOILER & 0 & 0 & 0 & 0 & 0 & 0 & 0 & 0 & 0 & 0 & 0 & 0 & 0 & 0 & 0 & 0 & 0 & 0 & 0 & 0 & 0 & 0 & 0 & 0 & 0 & 0 & 0 & 0 & 0 & & \\
\hline & TELE & 0 & 0 & 0 & 0 & 0 & 0 & 0 & 0 & 0 & 0 & 0 & 0 & 0 & 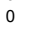 & 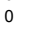 & 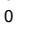 & 0 & 0 & 0 & 0 & 0 & 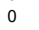 & 0 & 0 & 0 & 0 & 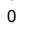 & o & 0 & 0 & 0 \\
\hline & TBLASTFUR & 0 & 0 & 0 & 0 & 0 & 0 & 0 & 0 & 0 & 0 & 0 & 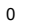 & 0 & 0 & 0 & 0 & 0 & 0 & 0 & 0 & 0 & 0 & 0 & 0 & 0 & 0 & 0 & 0 & 0 & & \\
\hline & TGASWKS & 0 & 0 & 0 & 0 & 0 & 0 & 0 & 0 & 0 & 0 & 0 & 0 & 0 & 0 & 0 & 0 & 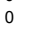 & 0 & 0 & 0 & 0 & 0 & 0 & 0 & 0 & 0 & 0 & 0 & 0 & & 0 \\
\hline & TCOKEOVS & 0 & 0 & 0 & 0 & 0 & 0 & 0 & 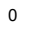 & 0 & 年 & 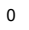 & 0 & 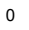 & 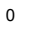 & 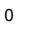 & 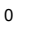 & 0 & 0 & 0 & 0 & 0 & , & 0 & 0 & 0 & 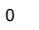 & 0 & 0 & 0 & 0 & 0 \\
\hline & TPATFUEL & 0 & 0 & 0 & 0 & 0 & 0 & 0 & 0 & 0 & 0 & 0 & 0 & 0 & 0 & 0 & 0 & 0 & 0 & 0 & 0 & 0 & 0 & 0 & 0 & 0 & 0 & 0 & 0 & 0 & 0 & 0 \\
\hline & TBKB & 0 & 0 & 0 & 0 & 0 & 0 & 0 & 0 & 0 & 0 & 0 & 0 & 0 & 0 & 0 & 0 & 0 & 0 & 0 & 0 & 0 & 0 & 0 & 0 & 0 & 0 & 0 & 0 & 0 & 0 & 0 \\
\hline & TREFINER & 0 & 0 & 0 & 0 & 0 & 0 & 0 & 0 & 0 & 0 & 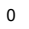 & 0 & 0 & 0 & 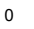 & 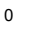 & 0 & 0 & 0 & 0 & r & 0 & 0 & 0 & - & 0 & 0 & 0 & 0 & 0 & 0 \\
\hline & TPETCHEM & 0 & 0 & 0 & 0 & 0 & 0 & 0 & 0 & 0 & 0 & 0 & 0 & 0 & 0 & 0 & 0 & 0 & 0 & 0 & 0 & 0 & 0 & 0 & 0 & 0 & 0 & 0 & 0 & 0 & 0 & 0 \\
\hline & TCOALLIQ & 0 & 0 & 0 & 0 & ${ }^{2}$ & 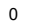 & 0 & 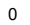 & ${ }^{2}+$ & $c_{0}>$ & 0 & 0 & 0 & 0 & 0 & 0 & 0 & 0 & 0 & 0 & 0 & 0 & 0 & 0 & 0 & 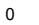 & 0 & 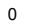 & 0 & 0 & 0 \\
\hline & TGTL & 0 & 0 & 0 & 0 & 0 & 0 & 0 & 0 & 0 & 0 & 0 & 0 & 0 & 0 & 0 & 0 & & 0 & 0 & 0 & 0 & 0 & & 0 & 0 & & 0 & 0 & 0 & 0 & 0 \\
\hline & TBLENDGAS & 0 & 0 & 0 & 0 & 0 & 0 & 0 & 0 & 0 & 0 & 0 & 0 & 0 & 0 & 0 & 0 & 0 & 0 & 0 & 0 & 0 & 0 & 0 & 0 & 0 & 0 & 0 & 0 & 0 & 0 & 0 \\
\hline & TCHARCOAL & 0 & 0 & 0 & 0 & 0 & 0 & 0 & 0 & 0 & 0 & 0 & 0 & 0 & 0 & 0 & 0 & 0 & 0 & 0 & 0 & 0 & 0 & 0 & 0 & 0 & 0 & 0 & 0 & 0 & 0 & 0 \\
\hline & TNONSPEC & 0 & 0 & 0 & 0 & 0 & 0 & 0 & 0 & 0 & 0 & 0 & 0 & 0 & 0 & 0 & 0 & 0 & 0 & 0 & 0 & 0 & 0 & 0 & 0 & 0 & 0 & 0 & 0 & 0 & 0 & 0 \\
\hline
\end{tabular}

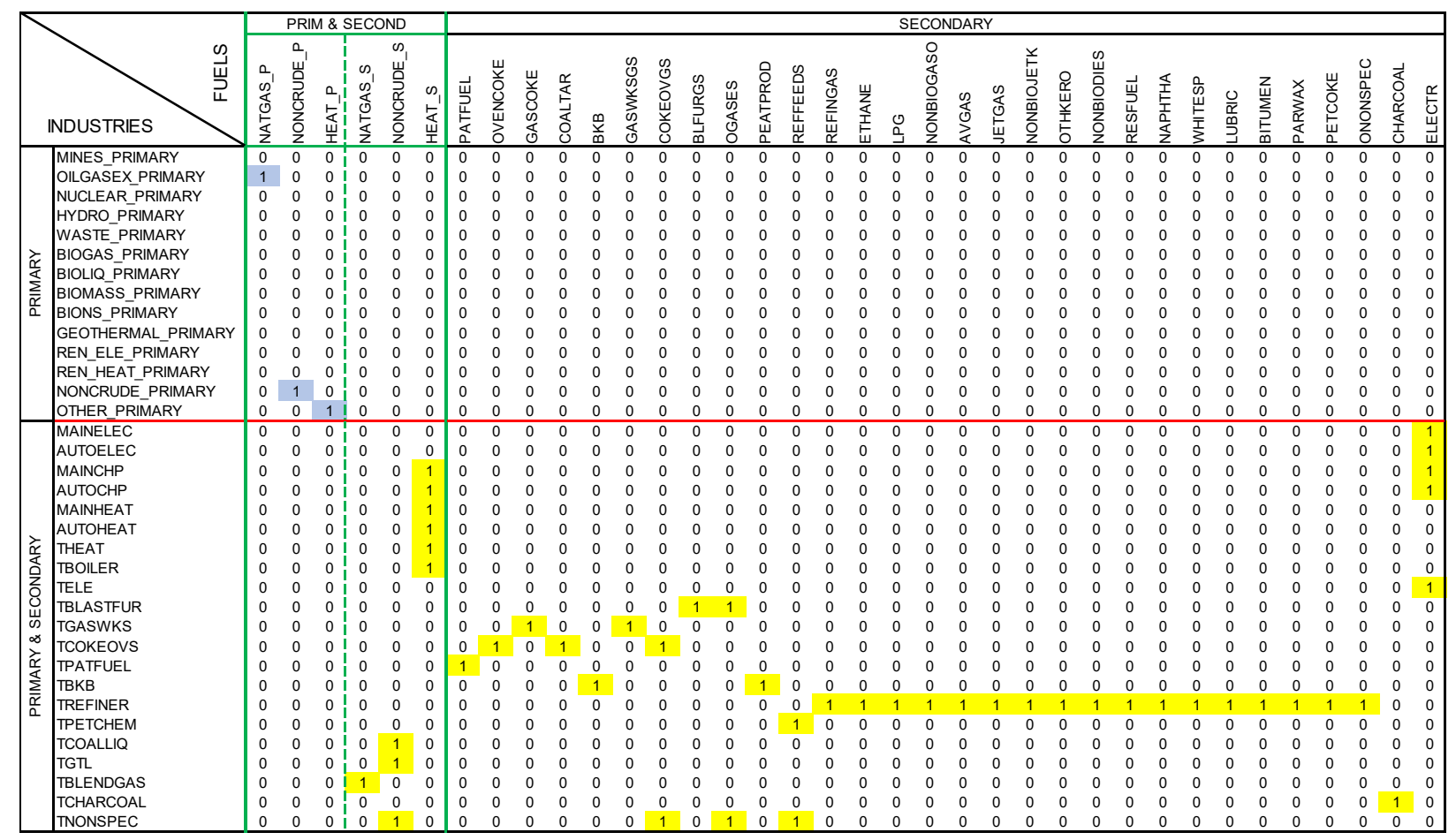

1 Primary energy

1 Secondary energy 